\title{
IMPACTS OF NATURAL SAPONIN PLANT EXTRACT WITHOUT OR WITH FRESH BAKER'S YEAST IN BUFFALOE HEIFERS RATIONS ON NUTRIENTS DIGESTIBILITY, SOME RUMINAL FERMENTATION AND BLOOD SERUM
} PARAMETERS.

Abdelmawla, S. M. S.

Animal production Dept., Faculty of Agric., Ain Shams University, Hadaek Shoubra 11241. Cairo, Egypt.

\begin{abstract}
In a trial lasted for 90 days to assess the impacts of a saponin plus glyco components (defaunator and ammonia binder) containing plant extract SCPE without or with fresh compressed (Baker's) saccharomyces cerevicia yeast culture (FSCYC) ( a probiotic) were used as feed additives to enhance rumen fermentation in buffalo heifer rations. Twenty buffalo heifers of an average weight of (248) $\mathrm{Kg}$ were allotted to four groups of five animals in each according to age and assigned at random to receive one of four dietary treatments. The treatments were: $\mathrm{T} 1$, received the basal ration BR (Control) that consisted of concentrate feed mixture: Egyptian berseem : rice straw (50:25:25 on dry matter basis), T2, received the BR plus $800 \mathrm{mg}$ of saponin containing extract, T3, received the BR plus $800 \mathrm{mg}$ saponin plus $10 \mathrm{~g}$ (FSCYC), and T4 received the BR plus $800 \mathrm{mg}$ saponin plus $20 \mathrm{~g}$ FSCYC.

Results of the supplementation with saponin only (T2) improved $(P<0.05)$ digestibility of organic matter $(\mathrm{OM})$, ether extract $(\mathrm{EE})$ and nitrogen free extract (NFE), while the introduction of FSCYC at10 or $20 \mathrm{~g}$ rates improved $(P<0.05)$ nutrients digestibility for all nutrients in T4, and T3 as compared to T2 and the control. The T4 group maintained its superiority $(P<0.05)$ above all groups for all nutrients except for DM digestion. Ruminal fluid $\mathrm{pH}$ tended to decrease with the introduction of additives in heifers rations where T4 was the lowest $(P<0.05)$. Ruminal ammonia-N concentration for the saponin only, T2 group, exhibited the lowest $(P<0.05)$ ruminal $\mathrm{pH}$, while the control group was the highest. Total volatile fatty acids (TVFA's) highest concentration was recorded for T4 while the control group was the lowest $(P<0.05)$. Heifers rations enrichment with SCPE and the FSCYC increased $(P<0.05)$ blood serum total proteins, albumin $(A)$ and globulin $(G)$ and $A / G$ ratio, where $T 4$ was the highest and the control was the lowest. However additives introduction in the rations decreased $(\mathrm{P}<0.05)$ serum urea, creatinine, cholesterol, GOT and GPT, where T4 was the lowest $(P<0.05)$ and the control was the highest $(P<0.05)$.

It could be concluded that ration supplementation with saponin containing natural plant extracts plus 10 or $20 \mathrm{~g}$ 's of FSCYC for buffalo heifers positively increased nutrient digestibility, with ruminal and blood serum indicator parameters were within the normal ranges for these biologics in buffaloes.

Keywords: fresh baker's Saccharomyces cerevicia yeast, natural saponin plant extract, buffalo heifers, nutrients digestibility, rumen fermentation parameters, blood.
\end{abstract}

\section{INTRODUCTION}

Many feed additives have been developed to improve the efficiency of nutrient utilization through decreasing the total amount of methane or ammonia $-\mathrm{N}$ produced, among which ionophore antibiotics have been very 
successful (Hutjens, 1992). Legislators in Europe have moved to prohibit the use of growth-promoting antibiotics in animal feeds from the end of the year 2005 (Chesson, 2004). This decision was based on public and political concerns that the heavy use of antibiotics in general can give rise to transmissible resistance factors that can compromise the potency of therapeutic antibiotics in man. Whether many of the commonly-used growth promoters present such a threat is the subject of intense debate; nevertheless, livestock producers in many countries must face a future without antibiotic growth promoters. For this reasons, there is substantial interest in evaluating the potential of natural antimicrobials such as plant extracts, generally recognized as safe for human consumption (FDA, 2004), to modify rumen microbial fermentation. Many alternative additives that would improve the efficiency of nutrient use in the rumen are plant produced secondary metabolites such as phenolic compounds, essential oils, and sarsaponins (Chesson et al., 1982; Wallace et al., 1994; Kamel, 2001) that affect microbial activity.

Because protozoa in the rumen cause protein turnover by predating on bacteria, and in fact, 8 to $12 \%$ of the digestible energy ingested by ruminants is lost in the rumen as methane, whereas from 75 to $85 \%$ of the $\mathrm{N}$ consumed by dairy cows is excreted in feces and urine (Tamminga, 1992), defaunation increases the nitrogen utilization of the ruminant and may lead to an increase in growth, milk, or wool production. Defaunation is the selective removal of protozoa from the rumen microbial ecosystem by a cell membrane cholesterol-saponin interaction, which causes cell rupture. The growthpromoting effect was evident in the high roughage diet suggesting that the application of saponins or saponin-containing plant materials may be beneficial for the subsistence farmers in developing countries, Wina et al., (2005). Also, Wina et al., (2005) reported that saponins, the steroid or triterpene glycoside compounds were found in a variety of plants. Some saponin-containing plants, mainly legumes. The beneficial effects of saponins numerous, the defaunation of rumen and manipulation of the end products of fermentation are good examples.

Historically, bacteria and yeasts have served man very well in agriculture and nutrition. Well-known examples are the use of bacteria (mainly lactic acid bacteria) for production of silage, and the use of yeasts (mainly Saccharomyces cerevisiae) for production of bread and other important products for the life of human beings. Today, modern animal nutrition has at its disposal a whole range of defined strains of probiotics belonging to the groups of lactic acid bacteria, Bacillus spores and yeasts (Hutjens, 2005).

The rumen is the key compartment for the ruminant to breakdown the plant structure to produce energy available for the host animal, in the form of volatile fatty acids (VFA: acetate, propionate, butyrate) (Russell, 2002).

Also, live yeasts have a documented efficacy on intestinal villi height and crypt depth, enhancing the assimilation of nutrients, and enhance modulation of the immune system by stimulation of $\mathrm{I} \mathrm{g}-\mathrm{A}$ response to pathogens (Qamar et al., 2001). 
Inclusion of yeast culture (Saccharomyces cerevisiae) in the diets of ruminants has been shown to increase nutrient digestibilities (Dawson,1993, El-Waziry et al., 2000, El-Ashry et al., 2001, El-Talty 2001, and Marghany et al., 2005), shift bacterial populations (Harris. and Lobo, 1988 and Hutjens 2005), increase the number of ruminal bacteria (Dawson 1993, Edwards et al., 1991; and Hutjens 2005), alter the flow of nitrogen fractions to the duodenum (Erasmus et al., 1992, Harrison et al 1988 and Wina et al., 2005), and increase milk yield (Robinson and Garrett, 1999, Dann et al, 2000, ElAshry et al., 2001, and Marghany et al., 2006). Moreover, benefits of supplementing ruminant rations with SCYC are: neutralization of certain bacterial toxins (Castagliuolo et al., 1999), adherence of flagellate bacteria, due to the presence of mannose receptors. Pathogens are eliminated by feces (Czerucka and Rampal 2002). Moreover, lactic bacteria, a beneficial flora, are increased, reinforcement of mucosal integrity and intestinal cells.

Therefore, the aim of the present experiment was to study effects of natural liquid containing saponin and glyco components extract (defaunator and ammonia binder) and the baker's SCYC (a probiotic) on feed intake, nutrients digestibility, some rumen and blood serum parameters using buffalo heifers.

\section{MATERIALS AND METHODS}

This study was conducted at the Agricultural Experiment Farm Station in Shalakan, at Kaluobeia Provence which belongs to The Faculty of Agriculture, Ain Shams University. Cairo, Egypt.

Animals and rations: Twenty buffalo heifers of average live body weight of $248 \mathrm{~kg}$ were used in 90 days trial. Buffalo heifers were allotted to four groups of five animals each according to age and assigned at random to receive one of four dietary treatments supplemented without or with the additive Fresh baker's Saccharomyces cerevisiae yeast culture FSCYC. The Fresh SCYC containing total cell count of 2.5-2.7×1010 and viable cell count of $1.3 \times 10^{9}$ $2 \times 10^{10}$ per gram (Grand Cairo Bakeries Company, Yeast Factory, Alsalam City, Cairo, Egypt. The second additive (saponin extract liquor) was a 50:50 $(\mathrm{v} / \mathrm{v})$ mixture of Mohave Yucca and Quillaja saponaria desert plants concentrated extracts from Nor-Feed, Denmark.

The experimental treatments were :(TI) -The control group received the basal ration $B R$, (T2) received the $B R+800 \mathrm{mg}$ saponin liquor (SL); (T3) received the $B R+10 \mathrm{gm}$ 's $+800 \mathrm{mg} \mathrm{SL}$ and (T4)- received the BR+ $20 \mathrm{gm}$ 's FSCYC+SL. The control ration consisted of concentrate feed. mixture (CFM) : Egyptian berseem (EB) : rice straw (RS); (50: 25 : 25, dry matter basis). The CFM consisted of $25 \%$ undecorticated cotton seed cake, $35 \%$. wheat bran, $30 \%$ com, $3 \%$ rice bran, $3 \%$ molasses, $2 \%$ limestone, $1 \%$ urea and $1 \%$ salt $(\mathrm{NaCl})$. The natural extract from the desert plants Mohave Yucca and Quillaja saponaria, contain saponins and glyco components - which has been calssified as natural feed flavoring materials (Valdez et al., 1986), it is classified as a food grade material, it is non-toxic and highly biodegradable. 
The extract is approved for use in food and beverages by the FDA under CFR 172.510, FEMA number 3121.

The chemical composition of the ration ingredients is shown in Table (1).

Management: Daily feeds were assessed to cover the requirements (of the heifers according to Shehata, (1970). The CFM was individually weighed for each animal and offered at 6.00 and $16.00 \mathrm{hr}$, while roughages were offered at 8.00 and $14.00 \mathrm{~h}$. after accessing the animals to fresh water at 7.00 and $15.00 \mathrm{hr}$. The daily supplementary yeast was mixed with CFM twice daily just before feeding to ensure that each animal had consumed its own dose of additive. Saponin containing liquor dose were mixed with drinking water for each group in the drinking pool at times of water drinking. The treatments were extended for 90 days.

Table (1): The experimental feed ingredients (Concentrate feed mixture CFM, Berseem forage, Rice straw, (RS), and the fresh Saccharomyces Cerevisia yeast culture ( FSCYC)* and the basal diet nutrients content.

\begin{tabular}{|l|c|c|c|c|c|c|c|}
\hline Item & $\begin{array}{c}\text { Dry } \\
\text { matter } \\
\text { (DM) }\end{array}$ & $\begin{array}{c}\text { Organic } \\
\text { matter } \\
\text { (OM) }\end{array}$ & Ash & $\begin{array}{c}\text { Crude } \\
\text { protein } \\
\text { (CP) }\end{array}$ & $\begin{array}{c}\text { Crude } \\
\text { fiber } \\
\text { (CF) }\end{array}$ & $\begin{array}{c}\text { Ether } \\
\text { Extract } \\
\text { (EE) }\end{array}$ & $\begin{array}{c}\text { Nitrogen free } \\
\text { extract (NFE). }\end{array}$ \\
\hline CFM & 92.6 & 90.1 & 9.0 & 14.1 & 13.4 & 2.7 & 59.9 \\
\hline Berseem & 12.3 & 88.2 & 11.8 & 13.8 & 27.3 & 2.6 & 46.9 \\
\hline Rice straw & 94.53 & 83.39 & 16.6 & 3.5 & 31.5 & 1.5 & 40.1 \\
\hline $\begin{array}{l}\text { Fresh baker's } \\
\text { yeast FSCYC }\end{array}$ & 29.0 & 92.6 & 7.4 & 44.3 & 6.5 & 3.0 & 38.8 \\
\hline
\end{tabular}

*S C Saccharomyces cerevisia (Compressed of fresh yeast).

Digestibility trials: Trial experimental periods were setup into three phases representing the first, second and third months of the trial study. By the end of each of the three months of the experimental periods, three animals from each experimental group were used in the digestibility trial. Feces was hand collected at 10.00 a. m. employing and following the Grab sample method for three successive days from each animal. The acid insoluble ash as internal marker was measured for determining the digestibility (Van Keulen and Young, 1977). Proximate chemical analysis was carried out according to the A. O. A. C. (1995) procedures, which were employed for the digestibility coefficients of studied nutrients calculations.

Sampling and analysis of rumen liquor: Rumen liquor ( $R L)$ samples were collected at the end of each month of the trial's three month periods, from the animals in the morning right before feeding (0 hour, (hr.), 2, 4, 6 hours (hrs.) post morning feeding using a rubber stomach tube with a vacuum pump Rumen liquor was strained through 4 layers of cheese cloth. The strained RL samples were divided into two portions, the first was for immediate determination of ruminal $\mathrm{pH}$ using a digital $\mathrm{pH}$ meter (EH-7010) and ammonia nitrogen was determined according to Conway (1962). The second portion was saved in glass bottles and treated with 0.5 milliliter toluene and 1 milliliter paraffin oil as preservatives and stop microbial fermentation activities, well sealed and kept frozen at -20 OC for later analyses. The 
ruminal total volatile fatty acids (TVFA's ) were determined in the strained RL according to Warner (1964).

Sampling and analysis of blood serum : Blood samples were withdrawn, at the end of month of the trial's three month periods, from the jugular vein from each animal 4 hours (hrs.) post morning feeding (pmf.). Collected blood samples were centrifuged at 4000 r.p.m. for $20 \mathrm{~min}$. and the blood serum was stored in clean glass vials at $-20^{\circ} \mathrm{C}$ till analysis. Serum total proteins were determined as described by Armstrong and Carr (1964), albumin (Doumas et al., 1971), urea (Patton and Crouch, 1977), and creatinine was determination Husdan (1968), transaminases (GOT and ,GPT) activities (Reitman and Frankel, 1957), cholesterol (Kostner et al., 1979). Globulin and albumin/globulin ratio $(\mathrm{A} / \mathrm{G})$ were calculated.

Analysis of feed samples: Samples of CFM, Egyptian Berseem, Rice Straw and Fresh baker's yeast were analyzed for dry matter (OM), ash crude protein (CP), crude fiber (CF) and ether extract (EE) according to A. O. A. Q (1995). Nitrogen-free-extract (NFE) was calculated by differences.

Statistical analysis: The ANOVA for a two-way classification design employing the general linear model procedure of SAS (Statistical Analysis Systems) with the model being:

$Y i j k=U+T i+e i k+A j+(T A) i j+E i j k$,

Where: Yijk : is the parameter under analysis of the ijk buffalo,

$\mathrm{U}$ : is the overall mean,

$\mathrm{Ti}:$ is the effect due to treatment,

ejk : is the effect due to the animals within treatment, (treatment error),

Eijk : is the effect due experimental error associated with the Yijk observation, according to Snedecor and Cochran, (1982).

\section{RESULTS AND DISCUSSION}

Nutrients digestibility: The results shown in Table (2) showed that the supplementation with saponin only $(\mathrm{T} 2)$ improved $(\mathrm{P}<0.05)$ digestibility of organic matter (OM), ether extract (EE) and nitrogen free extract (NFE), while the introduction of FSCYC at 10 or $20 \mathrm{gm}$ 's FSCYC rates improved $(\mathrm{P}<0.05)$ nutrients digestibility for all nutrients in T4, and T3 as compared to $\mathrm{T} 2$ and the control. The group of T4 (Saponin $+20 \mathrm{~g} \mathrm{FSCYC)} \mathrm{maintained} \mathrm{its}$ superiority $(\mathrm{P}<0.05)$ above all groups for all nutrients except for DM digestion. These results could be attributed to the suppression of ruminal protozoa, where the saponins are considered to have detrimental effects on protozoa through their binding with sterols present on the protozoal surface, while sterols are absent on bacterial membranes. (Hussain and Cheeke, 1995), and activation of ruminal bacteria which lead to decreasing methane emissions that would also lead to improved energy retention in the animal (Davidson and Naidu (2000), Wallace, (2007), and Busquet et al., (2006). The results exhibited that the additives enhanced the utilization of crude fiber, ether extract, and nitrogen free extract, which can be attributed to the increase in the production of VFA's which also may be attributed to the 
enhancement of celluololytic bacteria and its fuctions, These results are also supported by the findings of Hutjents (2005) who reported that yeast (a probiotic) and the natural extract from yucca plant (defaunator and ammonia binder) in ruminant rations supply metabolic compounds that destroy undesirable organisms, provide enzymes improving nutrient availability, or detoxify harmful metabolites.

Table (2): Mean values of live body weight, dry matter (DM) intake (I), nutrients digestibility and nutritive value of experimental rations fed to buffalo heifers.

\begin{tabular}{|c|c|c|c|c|c|}
\hline \multirow[b]{2}{*}{ ITEM } & \multicolumn{5}{|c|}{ Experimental treatments } \\
\hline & $\begin{array}{c}\text { Control } \\
\text { T1 }\end{array}$ & $\begin{array}{c}\text { T1+Saponin } \\
\text { (sap.) T2 }\end{array}$ & $\begin{array}{l}\text { T1 + Sap+ } \\
10 \text { g yst T3 }\end{array}$ & \begin{tabular}{|c|} 
T1 +Sap+20 \\
g yst T4 \\
\end{tabular} & $\stackrel{ \pm}{\mathrm{SE}}$ \\
\hline LBWT (Kg) & 270 & 236 & 217 & 269 & \\
\hline \multicolumn{6}{|l|}{ DM intake: } \\
\hline Total (Kg/head/day) & 10.0 & 10.0 & 9.7 & 9.7 & \\
\hline Total \% LBWT & 2.48 & 2.98 & 3.25 & 2.6 & 0.177 \\
\hline From CFM & 5.0 & 5.0 & 4.9 & 4.9 & \\
\hline From berseem & 2.5 & 2.5 & 2.4 & 2.4 & \\
\hline From rice straw & 2.5 & 2.5 & 2.4 & 2.4 & \\
\hline \multicolumn{6}{|c|}{ NUTRIENTS DIGESTIBILITY(\%): } \\
\hline Dry matter & $67.23^{\mathrm{b}}$ & $67.87^{b}$ & $75.36^{a}$ & $76.32^{a}$ & 0.290 \\
\hline Organic matter & $69.43^{d}$ & $73.35^{c}$ & $77.56^{\mathrm{b}}$ & $79.53^{a}$ & 0.185 \\
\hline Crude protein & $66.44^{\mathrm{c}}$ & $67.69^{c}$ & $69.84^{\mathrm{b}}$ & $72.11^{\mathrm{a}}$ & 1.259 \\
\hline Crude fiber & $57.68^{\mathrm{c}}$ & $58.70^{\mathrm{cb}}$ & $58.98^{b}$ & $60.80^{a}$ & 0.273 \\
\hline Ether Extract & $65.35^{d}$ & $67.50^{c}$ & $69.70^{b}$ & $76.90^{a}$ & 0.241 \\
\hline Nitrogen free extract & $68.60^{\circ}$ & $69.74^{b}$ & $69.96^{b}$ & $73.10^{a}$ & 0.111 \\
\hline
\end{tabular}

*Each value is a mean 3 animals; SE= Standard error of means; CFM=Concentrate feed mixture;

a,b,c,d Values in the same raw with different superscripts differ $(P<0.05)$ significantly

The improvement of $\mathrm{CP}$ digestibility $(\mathrm{P}<0.05)$ especially in $\mathrm{T} 3$ and $\mathrm{T} 4$ groups (saponin+FSCYC supplementation) which may be attributed to effect of saponin extract as reported by Makkar and Becker, (1997) where they found that saponins extract from plant Quillaja increased the efficiency of in vitro rumen-microbial protein synthesis and decreased degradability of feed protein. It is also important to mention that the inclusion of yeast culture Saccharomyces cerevisiae in the diets of ruminants has been shown to increase nutrient digestibilities (Dawson,1993), shift bacterial populations (Harrison et al., 1988), increase the number of ruminal bacteria (Dawson 1993, and Edwards et al., 1991), and alter the flow of nitrogen fractions, also, independent of the diet offered, a consistent effect of elimination of protozoa is a larger availability of amino acids for absorption at the small intestine amino acids of bacterial origin (Ushida et al 1988) and sometimes dietary origin (Michalowsky, 1988) to the duodenum (Erasmus et al., 1992, and Harrison et al., 1988).

Wherever protozoa consume large quantities of bacteria in the rumen. The protein breakdown which results, causes the net yield of microbial protein resulting from rumen fermentation to be decreased by up to 
$50 \%$. If the protozoa could be suppressed, there would be less ammonia formation and less need for dietary protein supplementation (Wallace, 2007). Ruminal parameters: Ruminal fluid $\mathrm{pH}$ values (Table 3 ) tended to decrease with the introduction of additives in heifers rations where T4 was the lowest $(P<0.05)$ which might be the result of the high $(P<0.05)$ conc. of VFA's produced in the rumen, these results are similar with those reported by Soliman, et al., (1997) on sheep received saponin powdered extract from Yucca schidigera at $500 \mathrm{mg} / \mathrm{h} / \mathrm{d}$ on sheep.

Table (3): Mean values of the rumen fluid parameters, $\mathrm{pH}$, Ammonia, and Volatile fatty acids withdrawn from the growing buffalo heifers at $0,2,4,6$ houres post morning feeding.

\begin{tabular}{|l|c|c|c|c|c|}
\hline \multirow{3}{*}{ ITEM } & \multicolumn{5}{|c|}{ Experimental treatments } \\
\cline { 2 - 6 } & Control & $\begin{array}{c}\text { T1+Saponin } \\
\text { (sap.) T2 }\end{array}$ & $\begin{array}{c}\text { T1 + Sap+ } \\
10 \text { g yst T3 }\end{array}$ & $\begin{array}{c}\text { T1 }+ \text { Sap }+20 \\
\text { gst T4 }\end{array}$ & SE \\
\hline
\end{tabular}

\section{Ruminal fluid pH:}

\begin{tabular}{|l|l|l|l|l|l|}
\hline 0 hour & $6.88^{\mathrm{a}}$ & $6.12^{\mathrm{b}}$ & $6.29^{\mathrm{b}}$ & $5.88^{\mathrm{c}}$ & 0.125 \\
\hline 2 hours & $6.70^{\mathrm{a}}$ & $6.40^{\mathrm{b}}$ & $6.43^{\mathrm{b}}$ & $6.20^{\mathrm{c}}$ & 0.125 \\
\hline 4 hours & $6.90^{\mathrm{a}}$ & $6.00^{\mathrm{b}}$ & $5.72^{\mathrm{c}}$ & $5.70^{\mathrm{c}}$ & 0.125 \\
\hline 6 hours & $6.40^{\mathrm{a}}$ & $5.50^{\mathrm{b}}$ & $5.50^{\mathrm{b}}$ & $5.20^{\mathrm{c}}$ & 0.125 \\
\hline
\end{tabular}

\section{Ruminal ammonia-N, $\mathbf{m g} / \mathbf{1 0 0} \mathrm{ml}$.:}

\begin{tabular}{|l|c|c|c|c|c|}
\hline $0 \mathrm{hr}$. & $13.69^{\mathrm{a}}$ & $12.18^{\mathrm{c}}$ & $12.59^{\mathrm{b}}$ & $11.78^{\mathrm{d}}$ & 0.297 \\
\hline $2 \mathrm{hrs}$. & $14.20^{\mathrm{b}}$ & $13.48^{\mathrm{c}}$ & $14.75^{\mathrm{a}}$ & $13.60^{\mathrm{c}}$ & 0.297 \\
\hline $4 \mathrm{hrs}$. & $13.55^{\mathrm{b}}$ & $12.29^{\mathrm{c}}$ & $14.52^{\mathrm{a}}$ & $13.10^{\mathrm{b}}$ & 0.297 \\
\hline $6 \mathrm{hrs}$. & $17.59^{\mathrm{a}}$ & $15.39^{\mathrm{b}}$ & $15.40^{\mathrm{b}}$ & $14.65^{\mathrm{c}}$ & 0.297 \\
\hline
\end{tabular}

Total Volatile fatty acids, $\mathrm{mmol} / \mathrm{ml}$ : :

\begin{tabular}{|l|l|l|l|l|l|}
\hline $0 \mathrm{hr}$. & $77.80^{\mathrm{c}}$ & $83.10^{\mathrm{b}}$ & $83.20^{\mathrm{b}}$ & $85.30^{\mathrm{a}}$ & 0.630 \\
\hline $2 \mathrm{hrs}$. & $86.20^{\mathrm{c}}$ & $86.30^{\mathrm{c}}$ & $86.80^{\mathrm{b}}$ & $89.70^{\mathrm{a}}$ & 0.970 \\
\hline $4 \mathrm{hrs}$. & $82.50^{\mathrm{c}}$ & $84.20^{\mathrm{b}}$ & $84.70^{\mathrm{b}}$ & $87.50^{\mathrm{a}}$ & 0.330 \\
\hline $6 \mathrm{hrs}$. & $76.20^{\mathrm{d}}$ & $79.60^{\mathrm{c}}$ & $82.20^{\mathrm{b}}$ & $85.70^{\mathrm{a}}$ & 0.440 \\
\hline
\end{tabular}

*Each value is a mean 3 animals; $S E=$ Standard error of means; CFM=Concentrate feed mixture;

a,b,c,d Values in the same raw with different superscripts differ $(P<0.05)$ significantly.

Ruminal ammonia-N: Ammonia-N concentration for the (only saponin supplemented group $(\mathrm{T} 2)$, exhibited the lowest $(\mathrm{P}<0.05)$ ruminal $\mathrm{pH}$, while the control group was the highest. The reduction in ammonia-N in (T2) may be attributed to the effect reported by Hussain and Cheeke, (1995) who stated that the extract from Yucca desert plant can also bind $\mathrm{NH} 4$ when ruminal $\mathrm{NH} 4$ concentrations are high, and release it again when ruminal $\mathrm{NH} 4$ is low, providing a continuous and adequate supply of $\mathrm{NH} 4$ for microbial protein synthesis, which is supported in this study with addition of fresh yeast culture to the diets $(T 3$, and T4) who achieved the highest $(P<0.05)$ nutrients digestibility coefficients, (Soliman et al., (1997), Dolezal and Dolezal (2005) and Jin et al., (2007).

Ruminal total volatile fatty acids (TVFA's) highest concentrations (conc.) was recorded for T4 while the control group was the lowest. $(\mathrm{P}<0.05)$ which is supported by Dolezal and Dolezal, (2005) 
Blood serum parameters: Results in Table (4) exhibited that heifers rations enrichment with additives (saponin or saponin + FSCYC) showed increased $(P<0.05)$ blood serum total proteins, albumin $(A)$ and globulin $(G)$ and $A / G$ ratio, where T4 was the highest and the control group was the lowest.; however our additives introduction in rations decreased $(P<0.05)$ serum urea, creatinine, cholesterol, GOT and GPT, where T4 was the lowest and the control was the highest. It is evident from our results that supplementation of saponin caused reduction $(\mathrm{P}<0.05)$ in heifers blood serum cholesterol which is supported by the study on the Masai people of East Africa who have low serum cholesterol levels despite a diet rich in animal fat. A number of studies, such as those of Malinow et al. (1977), have shown that alfalfa saponins have hypocholesterolemic activity in nonhuman primates. A number of synthetic saponins have been shown to be cholesterol absorption inhibitors (Harwood et al., 1993; Morehouse et al., 1999), causing reduction in plasma low-density-lipoprotein cholesterol fractions. Although it is generally accepted that the principal action of saponins on blood cholesterol is by sequestration of cholesterol and bile acids in the intestine, thus preventing the cholesterol from being recycled again into the blood stream again (Cheeke and Otero ( 2005) and Cheeke et al., (2006).

Table (4): Mean values of the blood serum parameters of the growing buffalo heifers.

\begin{tabular}{|l|c|c|c|c|c|}
\hline \multirow{2}{*}{ ITEM } & \multicolumn{5}{|c|}{ Experimental treatments } \\
\cline { 2 - 6 } & $\begin{array}{c}\text { Control } \\
\text { T1 }\end{array}$ & $\begin{array}{c}\text { T1+Saponin (sap.) } \\
\text { T2 }\end{array}$ & $\begin{array}{c}\text { T1 + Sap+ } \\
\mathbf{1 0} \mathbf{~ g ~ y s t ~ T 3 ~}\end{array}$ & $\begin{array}{c}\text { T1+ Sap+20 g } \\
\text { yst T4 }\end{array}$ & $\begin{array}{c}\mathbf{\pm} \\
\text { SE }\end{array}$ \\
\hline Total proteins, g/dL & $\mathbf{7 . 4 5 ^ { \mathrm { d } }}$ & $\mathbf{8 . 1 1 ^ { \mathrm { c } }}$ & $\mathbf{8 . 7 3 ^ { \mathrm { b } }}$ & $\mathbf{8 . 8 5 ^ { \mathrm { a } }}$ & $\mathbf{0 . 1 2}$ \\
\hline Albumin, g/dL. & $3.97^{\mathrm{d}}$ & $4.45^{\mathrm{c}}$ & $4.90^{\mathrm{b}}$ & $5.00^{\mathrm{a}}$ & 0.08 \\
\hline Globulin, g/d/L. & $3.48^{\mathrm{d}}$ & $3.66^{\mathrm{c}}$ & $3.83^{\mathrm{b}}$ & $3.85^{\mathrm{a}}$ & 0.03 \\
\hline Alb/glb ratio & $1.14^{\mathrm{d}}$ & $1.22^{\mathrm{c}}$ & $1.28^{\mathrm{b}}$ & $1.30^{\mathrm{a}}$ & 0.02 \\
\hline Urea-N, mg, d/L. & $35.45^{\mathrm{a}}$ & $32.35^{\mathrm{b}}$ & $28.74^{\mathrm{c}}$ & $22.65^{\mathrm{d}}$ & 1.31 \\
\hline Creatinine, mg/dL. & $1.63^{\mathrm{a}}$ & $1.58^{\mathrm{b}}$ & $1.41^{\mathrm{c}}$ & $1.20^{\mathrm{d}}$ & 0.04 \\
\hline Cholesterol, mg/dL. & $161.35^{\mathrm{a}}$ & $140.67^{\mathrm{b}}$ & $145.67^{\mathrm{c}}$ & $116.20^{\mathrm{d}}$ & 3.64 \\
\hline GOT, IU/L. & $43.69^{\mathrm{a}}$ & $42.34^{\mathrm{b}}$ & $38.68^{\mathrm{c}}$ & $34.79^{\mathrm{d}}$ & 0.69 \\
\hline GPT, IU/L. & $26.48^{\mathrm{a}}$ & $25.73^{\mathrm{b}}$ & $23.66^{\mathrm{c}}$ & $20.35^{\mathrm{d}}$ & 0.50 \\
\hline
\end{tabular}

${ }^{*}$ Each value is a mean 3 animals; SE= Standard error of means; CFM=Concentrate feed mixture;

a,b,c,d Values in the same raw with different superscripts differ $(P<0.05)$ significantly.

Aanother possible mode of action is via increased intestinal cell turnover rate. An increased rate of exfoliation of intestinal cells caused by the membranolytic action of saponins could result in increased loss of cell membrane cholesterol contained in the exfoliated cells (Gee and Johnson, 1988). The reduced level of serum urea might be a result of the increased efficiency of utilizing diet and microbial proteins due to the effects of saponin and FSCYC supplementation. The results of GOT and GPT point out to normal livers functioning of the heifers.

It could be concluded that ration supplementation with saponin containing natural plant extracts plus 10 or 20 gm's of FSCYC for buffalo heifers positively improved nutrient digestibility, with ruminal and serum 
indicator parameters were within the normal ranges for these biologics of buffaloes reported by El-Ashry et al., (1994) and El-Ashry, et al.,(2001).

\section{REFERENCES}

AOAC. (1990). Association of Official Analytical Chemists. 1990. Official methods of analysis, 15th edition. AOAC Inc., Arlington, VA.

Armstrong, W.O. and C.W. Carr (1964). Physiological chemistry: Laboratory Directions, $3^{\text {rd }}$ ed. PP. 75, Bburges Publishing Co. Minneapolis, Minnesota, USA.

Busquet, M., Calsamiglia, S., Ferret, A., Kamel, C. (2006). Plant Extracts Affect In Vitro Rumen Microbial Fermentation. J DAIRY SCI 89: 761771

Castagliuolo I., Riegler M.F., Valenick L., Lamont J.T. and Pothoulakis C. (999). Saccharomyces boulardii protease inhibits the effects of clostridium difficile Toxins A and B in Human Colonic Mucosa. Infect. Immun. 67: 302-307.

Cheeke, P. R. and R. Otero. (2005). Yucca, quillaja may have role in animal nutrition. Feedstuffs, (Suppl. 3):11-14.

Cheeke, P. R.; S. Piacente; and W. Oleszek. (2006). Anti-inflammatory and anti-arthritic effects of yucca schidigera: A review. Journal of Inflammation 2006, 3:6 doi:10.1186 /1476-9255-3-6.

Chesson, A., C. S. Stewart, and R. J. Wallace. 1982. Influence of plant phenolic acids on growth and cellulolytic activity of rumen bacteria. Appl. Environ. Microbiol. 44:597-603

Conway, E. J. (1958). Microdiffusio analysis and volumetric error. (4th. Ed.). The Macmillan Co., New York.

Czerucka, D., and Rampal, P. 2002. Experimental effects of Saccharomyces boulardii on diarrheal pathogens. Microbes and infection. 4: 733-739.

Dann, H. M., J. K I. Drackley, G. C. McCoy, M. F. Hutjens, and J.E. Garrett. (2000). Effects of yeast culture on prepartum intake and postpartum intake and milk production of Jersey cows. J. Dairy Sci. 83: 123.

Davidson, P. M., and A. S. Naidu. 2000. Phyto-phenols. Pages 265-293 in Natural Food Antimicrobial Systems. A. S. Naidu, ed. CRC Press, Boca Raton, FL.

Dawson, K. A. (1993). Current and future role of yeast culture in animal production: a review of research over the last seven years. Page 269 in Biotechnology in the Feed Industry. T. P. Ly-ons, ed. Alltech Tech. Publ., Nicholasville, KY.

Dolezal, P.; and Dolezal J. (2005). The yeast culture saccharomyces cereviciae (strain 47) as manipulator of rumen fermentation in post partal period of dairy cows. Acta Universitatis Agriculturae et Silviculturae Mendelianae Brunensis. Ustredni Kinh. MZLU v Brne, Brno, zech Repuplic:2005. 53:1, 27-33. 
Doumas, B.; W. Wabson and H. Biggs (1971). Albumin standards and measurement of serum with bromocresol green. Clin. Chem Acta, $31: 87$.

Edwards, I., T. Mutsavanga, J. Topps, and G. Paterson. 1991. Effect of supplementing yeast culture on patterns of rumen fermentation and performance of intensively fed bulls. Page 329 in Biotechnology in the Feed Industry. T.P. Lyons, ed. Alltech Tech. Publ., Nicholasville, KY.

El-Ashry, M.A; A.M. Kholif; H.A. El-Alamy; H.M. El-Sayed and T.A. ElHamamsy (2001). Effect of different yeast cultures supplementation to diet on the productive performance of lactating buffaloes. Egyptian $\mathrm{J}$. Nutrition and Feeds, 4 (1): 21

Erasmus L. J., P. M. Botha and A. Kistner. 1992. Effects of yeast culture supplement on produc- tion, rumen fermentation, and duodenal nitrogen flow in dairy cows. J. Dairy Sci. 75:3056.

EL-Talty, Y.I.; G.M. Abdul-Aziz and AM. Ali (2001). Calcium hydroxide treatment of some organic wastes. 2- Effect on performance of growing goats without or with yeast supplementation. Egyptian. J. Nutrition and Feeds.; 4:415.

EI-Waziry, AM.; HEM. Kamel and M.H.M. Yacout (2000). Effect of Baker's yeast (Saccharomyces cerevisiae) supplementation to berseem (Trifolium alexandrinum) hay diet on protein digestion and rumen fermentation of sheep. Egyptian J. Nutrition and Feeds, 3:71.

FDA. (2004). Food and Drug Administration of the US, 21 CFR 184.

Gee J.M. and I.T. Johnson. 1988. Interactions between Hemolytic Saponins, Bile Salts and Small Intestinal Mucosa in the Rat. Journal of Nutrition 118:1391-1397.

Harris, B. and R. Lobo (1988). Feeding yeast culture to lactating dairy cows. J. Dairy Sci., 71: Suppl., 1:276.

Harrison, G. A., R. W. Henken, K. A. Dawson, R. J. Harmon, and K. B. Barker. 1988. Influence of addition of yeast culture supplement to diets of lactating cows on ruminal fermentation and microbial populations. J. Dairy Sci. 71:2967.

Harwood HJ Jr, Chandler CE, Pellarin LD, Bangerter FW, Wilkins RW, Long CA, Cosgrove PG, Malinow MR, Marcetta CA, Pettini JL, Savoy YE and Mayne JT (1993) Pharmacologic consequences of cholesterol absorption inhibition: alteration in cholesterol metabolism and reduction in plasma cholesterol concentration induced by the synthetic saponin btigogenin cellobioside (CP-88818; tiqueside). Journal of Lipid Research 34, 377-395.

Husdan,H. (1968). Chemical determination of creatinine with deproteinization; Clin. Chem, 14:222.

Hussain, I. and P. R. Cheeke. (1995). Effect of Yucca scidigera extract on rumen and blood profiles of steers fed concentrate- or roughage-based diets. Animal Feed Science and Technology 51, 231-242.

Hutjens, M. F. (1992). Selecting feed additives. Pages 309-317 in Large Dairy Herd Management. H. H. Van Horn and C. J. Wilcox, ed. Am. Dairy Sci. Assoc., Champaign, IL. 
Hutjens, M. F. (2005). Managing variation in feed additives. Proc. Southwest Nutrition Conference. 32-2.

Jin, G. L.; Choi, S. K.; Choi, S. H.; and Song, M. K. (2007). Effect of microbial Additives on metabolic characteristics in sheep and milking performance of lactating dairy cows. Journa of Animal Science and Tecnol. Center. Seoul, Korea Repuplic: 2007. 49:6, 818-828.

Kamel, C. 2001. Tracing modes of action and roles of plant extracts in nonruminants. Page 135 in Recent dvances in Animal Nutrition. P. C. Garnsworthy, and J. Wiseman, ed. Nottingham Univ. Press, Nottingham, U.K..

Kostner, G.M., P. Avogaro, G. Bittolo Bon,G. Cazzolato and G.B. Quinci (1979). Determination of high-density lipoproteins: Screening methods compared. Clin. Chern. 25/6: 939.

Makkar, H. P. and K. Becker. 1997. Degradation of Quillaja saponins by mixed culture of rumen microbes. Lett. Appl. Microbiol. 25: 243-245.

Malinow, M.R., McLaughlin, P., Papworth, L., Stafford, C., Kohler, G.O., Livingston, A.L., Cheeke, P.R., 1977. Effect of alfalfa saponins on intestinal cholesterol absorption in rats. Am. J. Clin. Nutr. 30, 20612067.

Marghany, M., M. A. Sarhan, A. Abd El-Hey, and A. A. H. El-Tahan. (2005). Performance of lactating buffaloes fed rations supplemented with different levels of baker's yeast Saccharomyces cerevisiae. Egyp. J. Nutrition and Feeds. 8(1), Special Issue:21-34.

Michalowski, T. (1988). Importance of protein solubility and nature of dietary nitrogen for the growth of rumen ciliates in vitro. IN: The role of protozoa and fungi in ruminant digestion. Proceedings of a seminar held at the University of New England, Armidale, N.S.W. Australia. pp223-232.

Morehouse LA, Bangerter FW, DeNinno MP, Inskeep PB, McCarthy PA, Pettini JL, Savoy YE, Sugarman ED, Wilkins RW, Wilson TC, Woody HA, Zaccaro LM \& Chandler CE (1999) Comparison of synthetic saponin cholesterol absorption inhibitors in rabbits: evidence for a nonstoichiometric, intestinal mechanism of action. Journal of Lipid Research 40, 464-474.

Official Journal of the European Union. 2003. Regulation (EC) No 831/2003 of the European Parliament and of the Council of 22 September 2003 on Additives for Use in Animal Nutrition. Pages L268/29-L268/43 in OJEU of 10/18/2003.

Patton, C.J. and S.R. Crouch (1977). Spectrophotomitic and kinetics investigation of the berthelotteaCffon for the determination of ammonia, .... Anal. Chern., 49:464.

Qamar A., Aboudola S., Warny M., Michetti P., Pothoulakis C., Lamont J.T. and Kelly C.P. 2001. Saccharomyces boulardii Stimulates Intestinallmmunoglobulin A Immune Response to Clostridium difficile Toxin A in mice. Infect. Immun. (am. society for microbiology ).69: $2762-2765$. 
Reitman,S. and S. Frankel (1957). Colorimetric method forthe determination of serum glutamic-oxaloacetic and glutamic-pyrovate transaminase. Am.J. Clin. Path, 28:56.

Robinson, P.H., and J.E. Garrett. 1999. Effect of yeast culture on adaptation of cows to postpartum diets and on lactational performance. J. Animal Sci. 77:988.

Russell, J.B. 2002. Rumen Microbiology and Its Role in Ruminant Nutrition. Cornell University (Ithaca, NY) Ed., 122p.

SAS. (1992). SAS user's Guide, S.A.S. loc., Cary, N.S. U.S.A.

Shehata, O. (1970). Lectures in Animal Production. Fac., Agric. Ain Shams Univ. (in Arbic) .

Snedecor, G. W. and W.G. Cochran. (1JI82). Statistical Methods. $7^{\text {th. }}$ ed. lowa, lowa University Press. Ames, USA

Soliman, M.A.; F. A. Salem; D.M. EL-Kerdawy and S.H. Hassanin (1997). Yucca shidigera extract and 'yeast in sheep rations. - Egypt. J. Appl. Sci.,12(11): 1-20.

Tamminga, S. 1992. Nutrition management of dairy cows as a contribution to pollution control. J. Dairy Sci. 75:345-357.

Ushida, K., J. P. Jouany, C. Kayouli, and D. I. Demeyer. 1988. Effect of defaunation on fibre digestion in sheep fed ammonia-treated straw based diets. IN: The role of protozoa and fungi in ruminant digestion. Proceedings of a seminar held at the University of New England, Armidale, N.S.W. Australia. pp307- 308.

Valdez F.R., L.J. Bush, A.L. Goetsch \& F.N. Owens. 1986. Effect of Steroidal Sapogenins on Ruminal Fermentation and on Production of Lacting Dairy Cows. J. Dairy Sci. 69:1568-1575.

Van Keulen, J. and PAYoung (1977). Evaluation of acid insoluble ash as a natural marker in ruminant digestibility studies. J. Anim. Sci., 44: 282.

Wallace, R. J. et al., 1994. Influence of Yucca schidigera Extract on Ruminal Ammonia Concentrations and Ruminal Microorganisms. Applied and Environmental Microbiology. Vol. 60 No. 6 pp 1762-1767.

Wallace, R. J. (2007). Plant extracts as antimicrobials in ruminants. $41^{\text {st }}$ University of Nottingham Feed Conference. Rowett Research Institute, Bucksburn, Aberdeen, AB21 9SB. UK.

Warner, A. C. J. (1964). Production of volatile fatty acids in the rumen. Methods of measurements. Nut. Abstr. and rev. 34:339.

Wina, E; S. Muetzel and K. Becker. (2005). The impact of saponins or saponin containing plant materials on ruminant production-a review. J. Agric Food Chem.; 53(21):8093-105. 


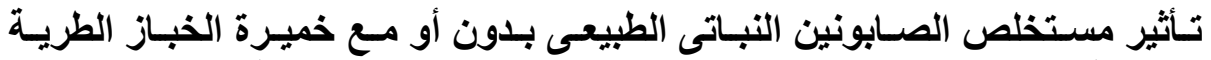

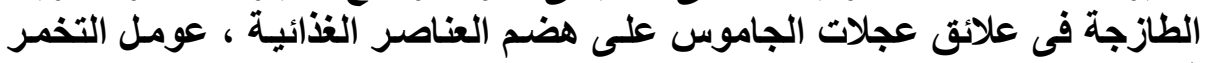

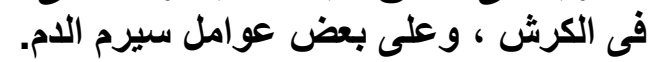

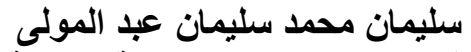
قسم الإتتاج الحيو انى - كلية الزراعة - جامعة عين شمس - حدائق شبرا 11241 ـ .

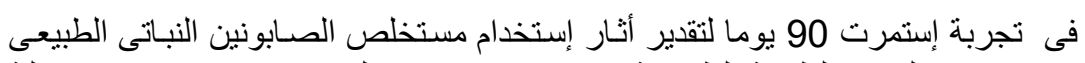

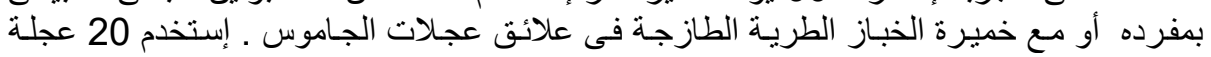

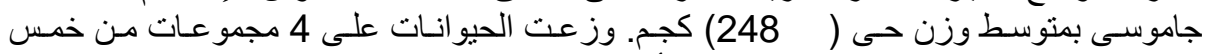

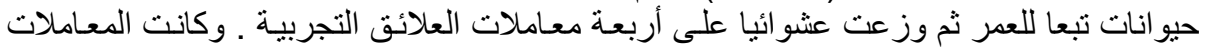

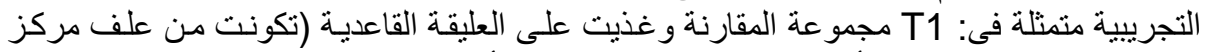

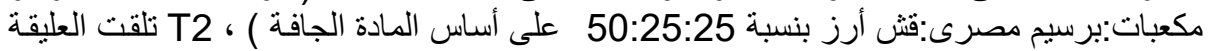

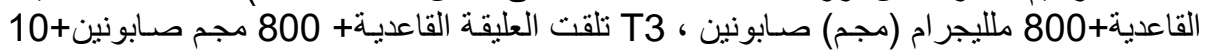

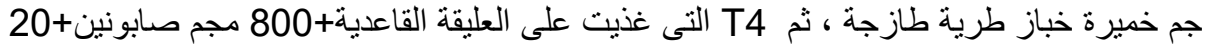

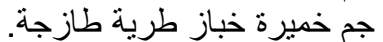
أظهرت نتائج المجمو عة الثانية (800 مجم صابونية (0.05) T2 تحسن هضم المادة الجافة و الدهن الخام

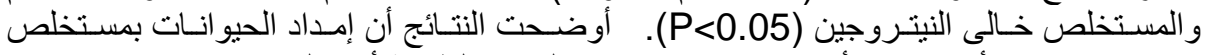

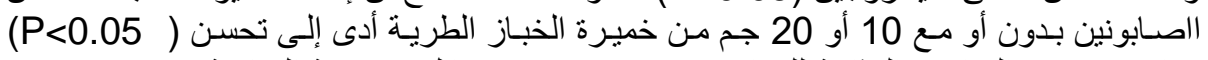

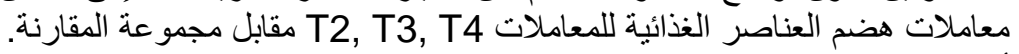

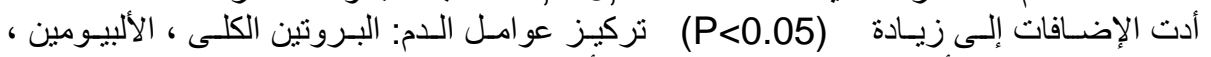

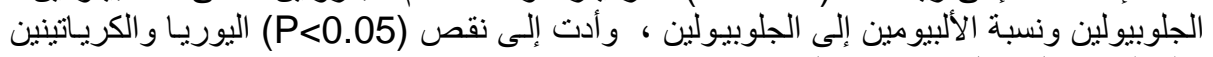
و الكوليستيرول وال

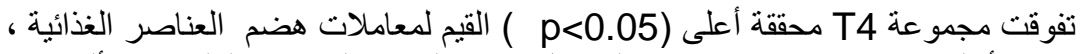

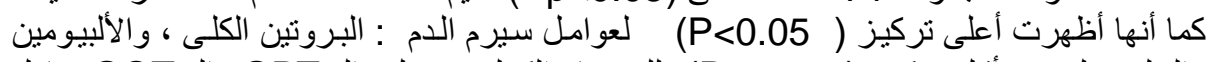
و الجلوبيولين ، و أقل تركيز (

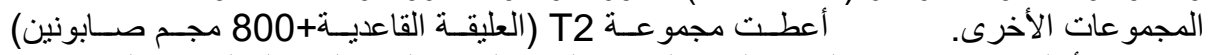

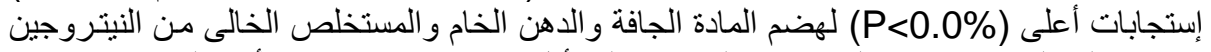

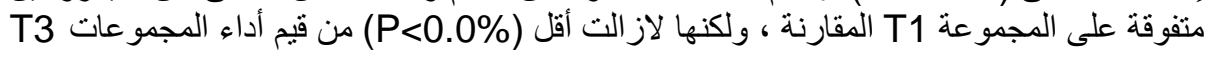

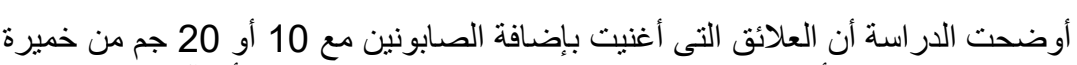
. T4



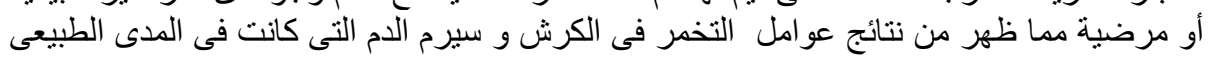

